\title{
The Effect of Light and Soil Moisture on the Environmental Behavior of Newts (Triturus vittatus vittatus, Urodela)
}

\author{
Gad Degani1,2 \\ ${ }^{1}$ Migal-Galilee Technology Center, Kiryat Shmona, Israel \\ ${ }^{2}$ School of Science and Technology, Tel-Hai Academic College, Tel Hai, Israel \\ Email: gad@migal.org.il
}

Received 27 July 2015; accepted 21 September 2015; published 24 September 2015

Copyright (C) 2015 by author and Scientific Research Publishing Inc.

This work is licensed under the Creative Commons Attribution International License (CC BY). http://creativecommons.org/licenses/by/4.0/

(c) (i) Open Access

\begin{abstract}
The response to hiding places of metamorphosed newts (Triturus vittatus vittatus) affected by light and moisture was studied under experimental conditions. No significant differences $\left(\mathrm{X}^{2}\right.$-test; $P>0.05$ ) were found in the choice of hiding places covered with black or transparent paper as the control of the experimental methods. The selection of hiding places by the newts is significant regarding soil moisture and negative phototoxicity. Significant differences $\left(X^{2}\right.$-test; $\left.P<0.05\right)$ were found in the choice of hiding places between those covered by black paper and those covered by the different colors of light paper: colorless, yellow, red, blue and green. The negative phototoxicity differs according to wavelength and differs from dark to other colors, and to transparent changes according to wavelength. The response to moisture was stronger than to light. Juvenile $T$. $v$. vittatus chose moist soil in hiding places covered by black or transparent paper in all the various combinations, and the difference was significant $\left(X^{2}\right.$-test; $\left.P<0.001\right)$.
\end{abstract}

Keywords

Behavior, Hiding Places, Moisture, Triturus vittatus, Wavelength

\section{Introduction}

The urodele species, Triturus vittatus (Gray, 1835; see Litvinchuk et al. (2005) [1]), is distributed throughout western Caucasus, Turkey, Lebanon, Syria, Israel, Iraq and possibly Jordan. Borkin et al. (2003) [2] have provided a list of all known records of $T$. vittatus. Litvinchuk et al. (2005) [1] have suggested that the banded newt, T. vittatus, consists of two species, T. ophryticus and T. vittatus, based on trunk vertebrae count, genome size 
and allozyme data. The northern taxon, T. ophryticus, is subdivided into two geographic fragments: "western group" populations from western Anatolian Turkey, and "eastern group" populations distributed in the remaining area of Pontic Turkey and Western Caucasus. According to the above criteria, the T. vittatus species is found in Israel.

The biology and life cycle of T. vittatus in Europe and in the Mediterranean region have been described by Olgun et al. (1997) [3]. As indicated by their data, there are two known subspecies in the genus Triturus: T. v. vittatus along the eastern edge of the Mediterranean Sea from Turkey to Israel, where it reaches its southern limit, and T. v. ophryticus in the Caucasus, east and south of the Black Sea. The banded newt, T. v. vittatus, is an endangered species in Israel (Geffen et al., 1987) [4]. Moreover, other species and subspecies of this genus are endangered in other regions of the world. At the southern limit of the T. v. vittatus distribution (in Israel), environmental conditions are the most extreme. Limiting factors are likely to be breeding sites and dryness of the terrestrial habitat. The biology and life cycle of $T$. v. vittatus in northern Israel and the upper Galilee have been described by Degani and Mendelssohn (1983) [5] and Pearlson and Degani (2008) [6], while a population in central Israel has been reported by Geffen et al. (1987) [4]. T. v. vittatus inhabits mainly winter pools that contain water only until the beginning of the summer, although occasionally these pools have water throughout the year (Degani and Kaplan, 1999) [7]. Like other newts, T. v. vittatus requires water bodies surrounded by an adequate terrestrial habitat to support both life phases. If either habitat is damaged, a population may be unable to survive. The adaptation of $T$. v. vittatus to semi-arid conditions at the southern border of its distribution was found to be achieved by the modification of its gonadal cycle and growth rate. The ovaries of $T$. v. vittatus are of the synchronic type. Aquatic females have a defined batch of mature oocytes, as well as oocytes at different stages of development: oogonia, chromatin nucleolus, and perinuclear and vitellogenic oocyte maturation. Some aquatic females were more developed than others, harboring not only oocytes at different stages of vitellogenesis, but also mature oocytes with nuclear migration. In contrast, ovaries of terrestrial forms had only pre-vitellogenic and atretic oocytes [8]. The male gonads, which consisted of seminiferous tubules, contained cysts of cells at different developmental stages. In aquatic forms, spermatogonia, spermacytes, spermatides and spermatozoa were observed in the gonads [8]. The ecological and biological conditions of breeding sites inhabited by T. v. vittatus in northern Israel were studied for four years. These results support the hypothesis that changes in the rate of larval growth and metamorphosis completion are the manner by which $T$. v. vittatus adapts to unstable breeding sites. Based on the results of the investigation, the major factors affecting the habitat selected by T. v. vittatus for breeding are the ecological conditions that allow for survival, growth and metamorphosis completion of the amphibian larvae [9].

The adaption to terrestrial metamorphosed newts has been studied less compared to aquatic phase and larvae growth. The adaption depends on physiology suitability [10] to terrestrial life, environmental behavior [11], and the ability to find hiding places to prevent dehydration. The food of the species $T$. v. vittatus was studied mainly in the aquatic phase or in larvae [12]; much less information was available about metamorphosed newts. Adult $T$. v. vittatus feeds on a wide range of terrestrial and aquatic invertebrates but may exhibit some degree of food selection [4]. Metamorphosed newts are active at night and during the day in selected hiding places in holes and under shelters such as stones to prevent dehydration. However, the parameters affecting the selection of hiding places, which are very important for adaption to terrestrial life particularly at the southern border of its distribution where the newts are found in relatively extreme conditions, are very important. The hypothesis examined in the current study is that the selection of hiding places by newts is significantly affected by soil moisture and negative light (negative photo taxis).

\section{Materials and Methods}

\subsection{Animals}

Larvae of T. v. vittatus were collected by nets from the Sasa pond in April, as previously described by Degani (1982) [13], and maintained in aquariums $(20 \times 10 \times 10 \mathrm{~cm})$, half with water and the other half with stones so that the larvae that had completed metamorphosis could climb on the stones. The juvenile newts were maintained in five containers $(20 \times 10 \times 10 \mathrm{~cm}), 20$ newts per container.

\subsection{Experiment Description}

The study was carried out in a large aquarium whose sides were covered with black cloth. The top of the aqua- 
rium was covered with different colored transparent paper. The aquarium measured $60 \times 35 \times 40 \mathrm{~cm}$ and was fitted with soil, with two of the sides containing holes $10 \mathrm{~cm}$ deep. The experiment was conducted at room temperature $\left(20^{\circ} \mathrm{C}-25^{\circ} \mathrm{C}\right)$. Half of the aquarium was covered with colored transparent paper and the other half with a different colored transparent paper. The combinations of different colored paper are presented in Figures 1-4. Each combination was repeated four times and the aquarium was turned $450^{\circ}$ after each repetition; 50 newts were used in each group.

The experiment started at 8:00, and the number of juvenile newts was examined after 1, 2, 4, 8 and 24 hours. To study the effect of soil moisture on the different light colors of newts, the aquarium was divided in the middle by glass panes into two equal parts. Half of each aquarium was moistened with 11 water and the other half was kept dry. The first set of experiments and each color combination was performed twice, each time the moisture was on a different side of the transparent colored paper.

\section{Results}

No significantly differences $\left(\mathrm{X}^{2}\right.$-test; $\left.\mathrm{P}>0.05\right)$ were found in choosing hiding places covered by black or transparent paper in the control of the current study (Figure 1). No significant differences were found by the newts in choosing hiding places covered by green and blue or red and blue paper (Figure 1). A clear response of juvenile T. v. vittatus to hiding places covered with black paper compared to the other different light colors was found: colorless, yellow, red, blue and green (Figure 2).

The negative phototoxic change differs according to wavelength, and the differences between dark to other colors and to transparent colors vary according to wavelength. The responses to the black cover were significantly higher than to all the other colors $\left(\mathrm{X}^{2}\right.$-test; $\mathrm{P}<0.001$ ) (Figure 2 ). The response to moisture was stronger than to light. Juvenile $T$. $v$. vittatus chose moist soil in black or transparent covered hiding places for all the various combinations (Figure 3); the difference was significant $\left(\mathrm{X}^{2}\right.$-test; $\left.\mathrm{P}<0.001\right)$.

\section{Discussion}

The life history of Triturus v. vittatus (Urodela) is relatively detailed and is described in the southern border of its distribution [4]-[6] [8] [9]. However, most of the studies described the larvae growth or aquatic phase of the life cycle. Less emphasis was placed on the adaption to terrestrial life. In the current study, two parameters af-
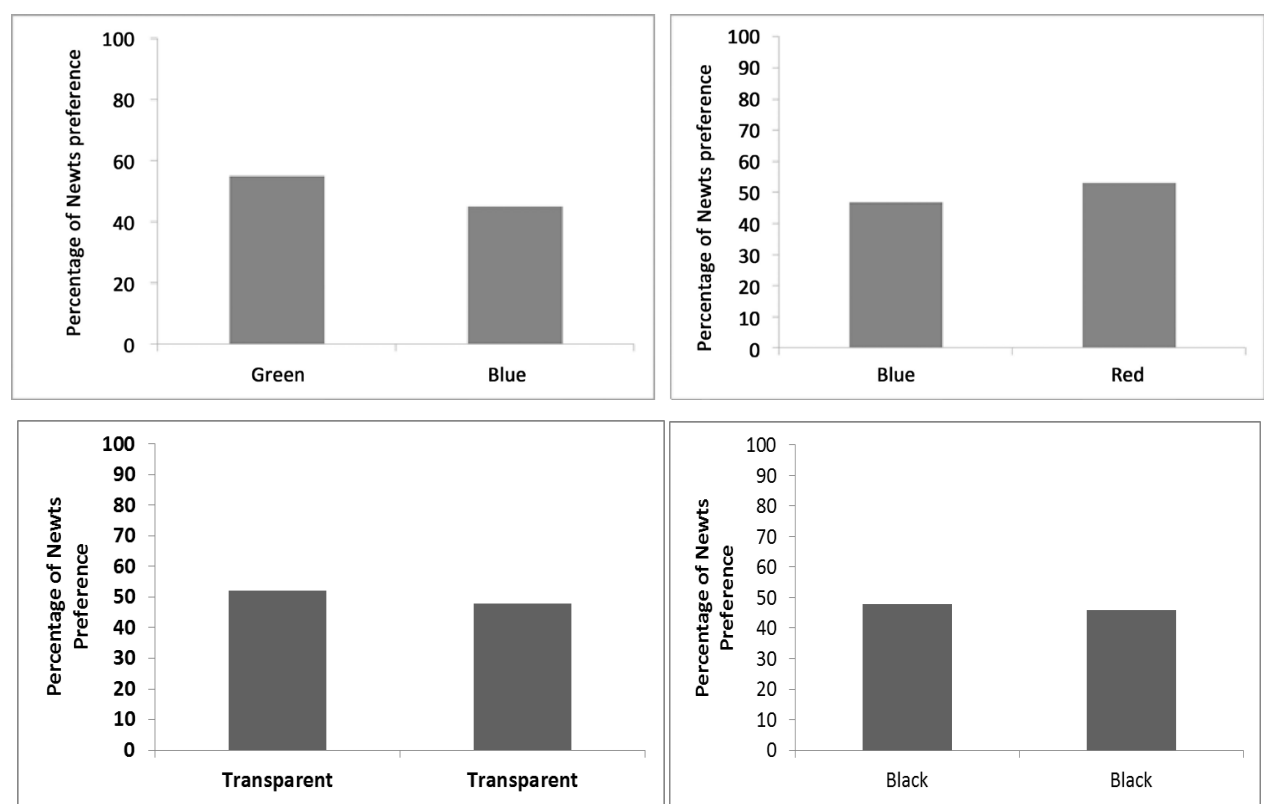

Figure 1. Comparison of the behavior of metamorphosed juvenile newts (Triturus vittatus vittatus) in seeking hiding places covered with different colors of transparent paper (no. of animals used in the experiment was 50 newts; each experiment was run five times). No significant differences were found between the various colors represented in this figure $\left(\mathrm{X}^{2}\right.$-test; $\mathrm{P}>$ $0.05)$. 

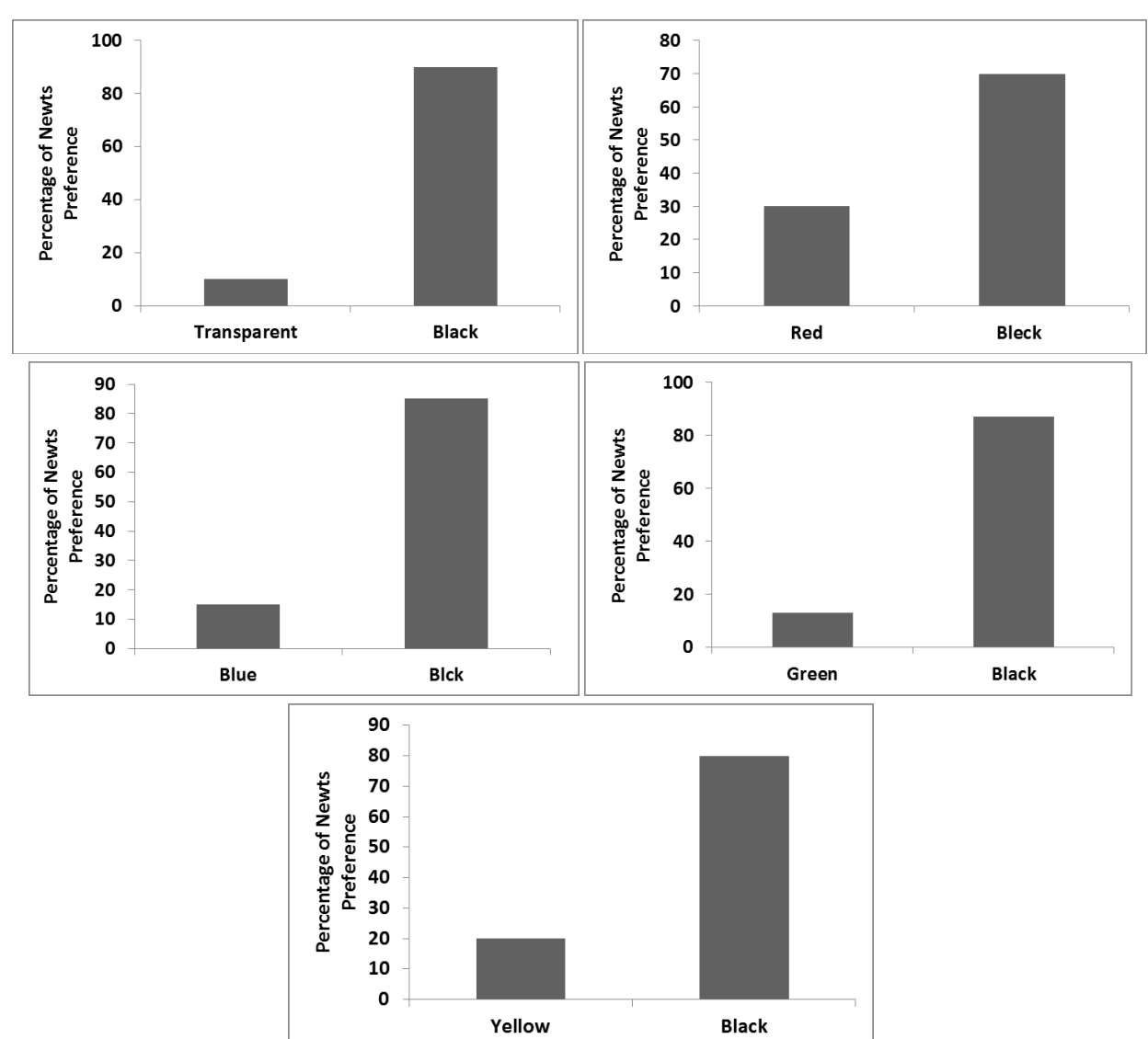

Figure 2. Comparison of the behavior of metamorphosed juvenile newts (Triturus vittatus vittatus) in seeking hiding places covered with black transparent paper to hiding places covered with different colored paper (no. of animals used in the experiment was 50 newts; each experiment was run five times). Significant differences were found between the black paper and the different colored papers $\left(\mathrm{X}^{2}\right.$-test; $\left.\mathrm{P}<0.01\right)$.

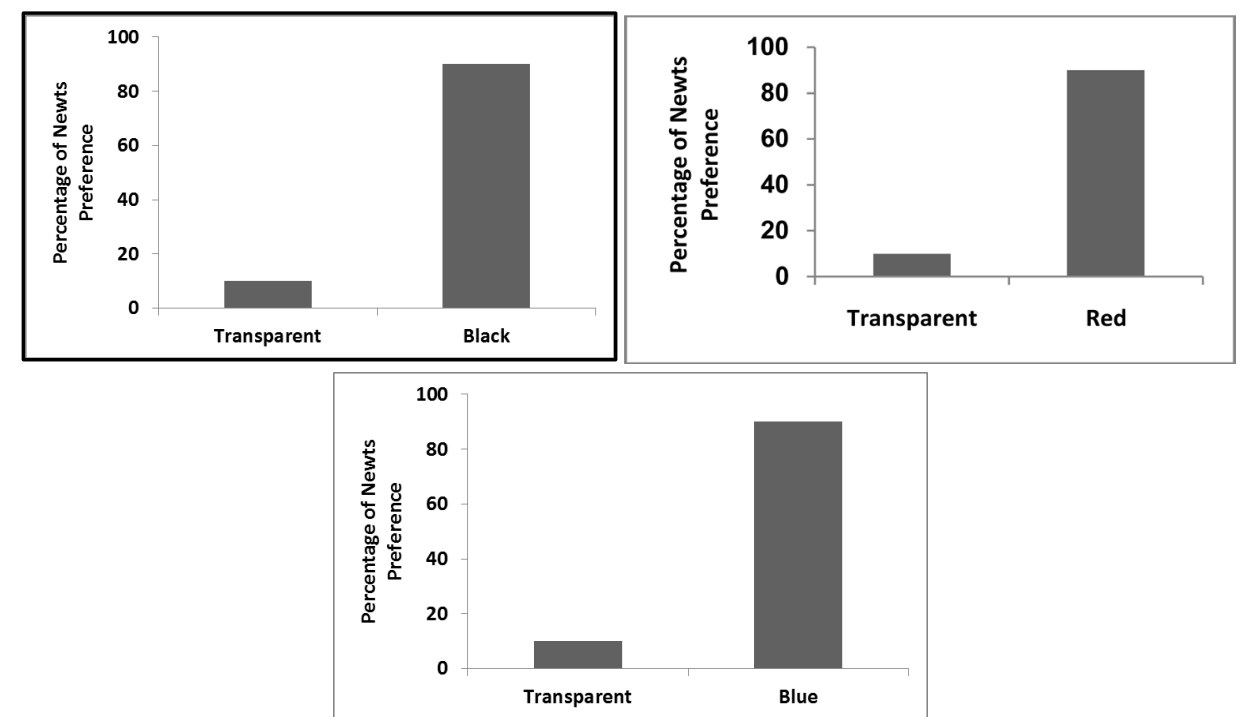

Figure 3. Comparison of the behavior of metamorphosed juvenile newts (Triturus vittatus vittatus) in seeking hiding places covered with transparent paper to hiding places covered with different colored paper (no. of animals used in the experiment was 50 newts; each experiment was run five times). Significant differences were found between the transparent paper and the different colored paper $\left(\mathrm{X}^{2}\right.$-test; $\left.\mathrm{P}<0.01\right)$. 

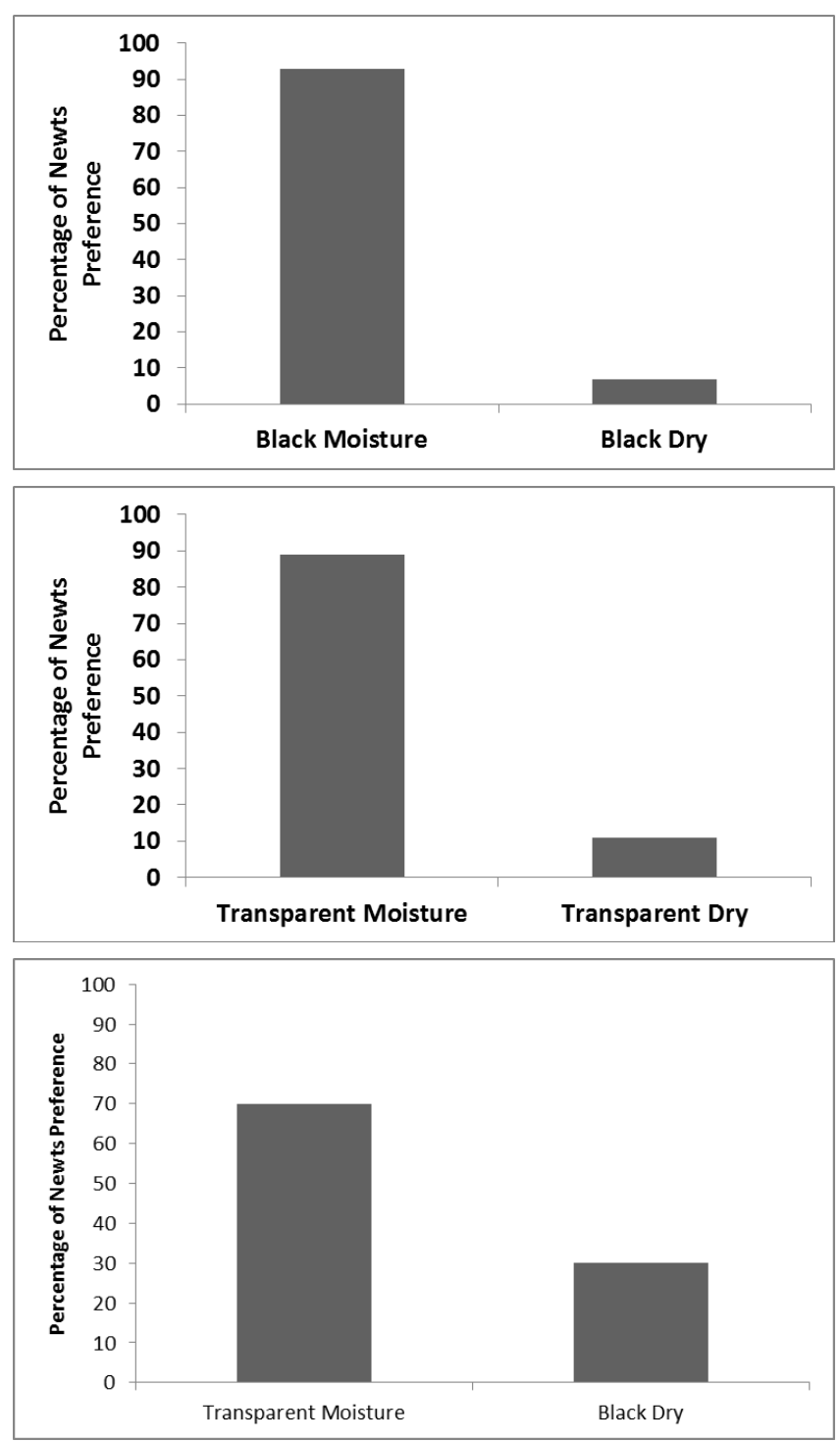

Figure 4. Comparison of the behavior of metamorphosed juvenile newts (Triturus vittatus vittatus) in seeking hiding places with different covered paper and moisture levels (no. of animals used in the experiment was 50 newts; each experiment was run five times). Significant differences were found between moisture levels with different colored paper covering the selected hiding places $\left(\mathrm{X}^{2}\right.$-test; $\left.\mathrm{P}<0.01\right)$.

fecting the behavior of terrestrial phases in seeking hiding places by Triturus v. vittatus were examined: light and soil moisture, and the interaction between them. Both parameters significantly affected the newts' behavior. The results of the current study were in agreement with Degani (1982), who discovered that the hiding places of Triturus v. vittatus in upper Galilee were only in moist soil, under stones and in holes [11]. The current study showed that although moisture in the hiding places was very important, wavelength was also affected. However, the current study showed that soil moisture was more important than negative phototoxic in selected hiding places by Triturus v. vittatus. A comparative survey of 127 species of adult anuran (tailless) amphibians drawn from all six sub-orders and all but one of the 17 families revealed three basic phototactic responses to spectrally dominant stimuli, which were studied by Hailman and Jaeger (1977) [14]. Regarding anuran preference for light, some species (photopositive) are attracted to light while others (photonegative) are not [15]. In terrestrial Urodela, as in the current study, negative phototactic responses were observed, as was found in Triturus v. vittatus [16] [17]. In the current study, the negative phototactic response differed according to wavelength, and the difference between dark and other colors changed according to wavelength (Figure 5). 


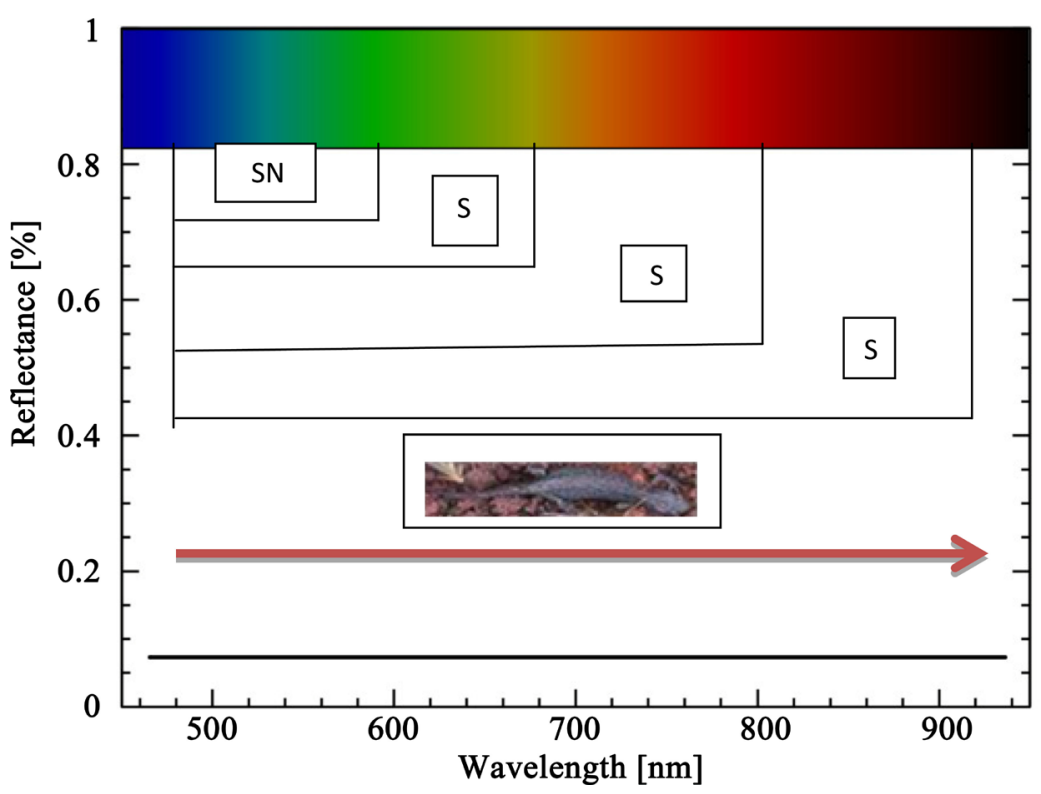

Figure 5. Suggested model for the response by Triturus vittatus vittatus to various hiding places affected by wavelength $(\mathrm{WL}) . \mathrm{S}=$ significant differences $\left(\mathrm{X}^{2}\right.$-test; $\left.\mathrm{P}<0.01\right)$ among $\mathrm{WL}, \mathrm{NS}=$ not significant $\left(\mathrm{X}^{2}\right.$-test; $\left.\mathrm{P}>0.05\right)$ differences among WL.

The results of the current study support the hypothesis that in Urodela, this negative phototoxic affects adaption to terrestrial life in find hiding places. In Ambystoma opacum, the negative phototoxic developed during metamorphosis [16] [17].

In Israel, two Urodela were found, Triturus v. vittatus and Salamandra infraimmaculata, at the southern border of its distribution in the extreme condition of these species [18]-[20].

Triturus $v$. vittatus is found in more southern and extreme conditions than S. infraimmaculata in Israel [21][25]. There is no better physiological adaption of newts to terrestrial life than salamanders [10]. One of the possibilities explaining the survival of newts in more extreme conditions than salamanders in Israel is the small body size of Triturus $v$. vittatus [5] compared to S. infraimmaculata [18]-[20], and the different behavior by newts in seeking hiding places, whereby negative phototoxic and moisture preference and their small body size help prevent dehydration.

\section{References}

[1] Litvinchuk, S.N., Zuiderwijk, A., Borkin, L.J. and Rosanov, J.M. (2005) Taxonomic Status of Triturus vittatus (Amphibia: Salamandridae) in Western Turkey: Trunk Vertebrae Count, Genome Size and Allozyme Data. Amphibia-Reptilia, 26, 305-323. http://dx.doi.org/10.1163/156853805774408685

[2] Borkin, L.J., Litvinchuk, S.N. and Zuiderwijk, A. (2003) Bandmolch, Triturus vittatus (Gray, 1835). In: Grossenbacher, K.G. and Thiesmeier, B., Eds., Handbuch der Reptilien und Amphibien Europas, Bd. 4/IIA: Schwanzlurche (Urodela) IIA, AULAVerlag, Wiesbaden, 555-605.

[3] Olgun, K., Tok, V., Arntzen, J. and Turkozan, O. (1997) The Taxonomic Status of the Banded Newt (Triturus vittatus) in Southern Turkey. Herpetological Journal, 7, 169-171.

[4] Geffen, E., Gafny, S. and Gasith, A. (1987) Contribution to the Knowledge of the Biology of the Banded Newt, Triturus vittatus vittatus, in Rainpools in Israel. Israel Journal of Zoology, 34, 213-223.

[5] Degani, G. and Mendelssohn, H. (1983) The Habitats, Distribution and Life History of Triturus vittatus vittatus (Jenyns) in the Mount Meron Area (Upper Galilee, Israel). British Journal of Herpetology, 6, 317-319.

[6] Pearlson, O. and Degani, G. (2008) The Life History of Triturus v. vittatus (Urodela) in Various Habitats. Asiatic Herpetological Research, 11, 91-95.

[7] Degani, G. and Kaplan, D. (1999) Distribution of Amphibian Larvae in Israeli Habitats with Changeable Water Availability. Hydrobiologia, 404, 49-56. http://dx.doi.org/10.1023/A:1003796820900

[8] Degani, G., Pearlson, O. and Goldberg, T. (2013) Impermanent Breeding Site Selection-Fitness of Gonadal Cycle and 
Larval Growth of Triturus vittatus vittatus (Urodela) from the Southern Limit of Its Distribution. Amer. Open. Anim. J, 1, 16-30.

[9] O.D. Pearlson, G. (2011) Water and Ecological Conditions of Striped Newt, Triturus v. vittatus (Urodela), Breeding Sites at Various Altitudes near the Southern Limit of Its Distribution. Herpetol. Romanica, 5, 27-42.

[10] Warburg, M.R. (1971) The Water Economy of Israel Amphibians: The Urodeles Triturus vittatus (Jenyns) and Salamandra salamandra (L). Comparative Biochemistry and Physiology, 40A, 1055-1063. http://dx.doi.org/10.1016/0300-9629(71)90294-5

[11] Degani, G. (1982) The Response to Substrate Moisture of Triturus vittatus ophryticus (Jenys) (Amphibia, Urodela). Behavioral Biology, 3, 215-220.

[12] Kutrup, B., Cakir, E. and Yilaaz, N. (2005) Food of the Banded Newt, Triturus vittatus ophryticus (Berthold, 1846), at Different Sites in Trabzon. Turkish Journal of Zoology, 29, 83-89.

[13] Degani, G. (1982) Amphibian Tadpole Interaction in Winter Pond. Hydrobiologia, 96, 3-7. http://dx.doi.org/10.1007/BF00006274

[14] Hailman, J.P. and Jaeger, R.G. (1974) Phototactic Responses to Spectrally Dominant Stimuli and Use of Colour Vision by Adult Anuran Amphibians: A Comparative Survey. Animal Behavior, 22, 757-795. http://dx.doi.org/10.1016/0003-3472(74)90002-5

[15] Kicliter, E. and Goytia, E.J. (1995) A Comparison of Spectral Response Functions of Positive and Negative Phototaxis in Two Anuran Amphibians, Rana pipiens and Leptodactylus pentadactylus. Neuroscience Letters, 185, 144-149. http://dx.doi.org/10.1016/0304-3940(94)11242-B

[16] Przyrembel, C., Keller, B. and Neumeyer, C. (1975) Trichromatic Color Vision in Salamander (Salamandra salamndra) Journal of Comparative Physiology A, 176, 575-586.

[17] Marangio, M.S. (1975) Phtotaxis in Larvae and Adults Salamanders, Ambystoma opacum. Journal of Herpetology, 9 , 293-297. http://dx.doi.org/10.2307/1563194

[18] Degani, G. (1996) The Salamander at the Southern Limit of Its Distribution. Laser Pages Publishing, Israel.

[19] Degani, G. (1986) Plasma Protein and Morphology of Salamandra salamandra in Israel. Amphibia-Reptilia, 7, 105114. http://dx.doi.org/10.1163/156853886X00334

[20] Degani, G. (1986) Osmotic Stress and Osmoregulation of Tadpoles and Juveniles Pelobates syriacus. Comparative Biochemistry and Physiology Part A, 83, 365-370. http://dx.doi.org/10.1016/0300-9629(86)90591-8

[21] Pearlson, O. and Degani, G. (2007) Molecular DNA Variations among Triturus vittatus vittatus (Urodela) from Different Breeding Sites at the Southern Limit of Its Distribution. Acta Herpetological Journal, 2, 69-77.

[22] Pearlson, O. and Degani, G. (2007) Triturus v. vittatus (Urodela) Larvae at Various Breeding Sites in Israel. Progrese si Perspective in Medicina Veterinara, 50, 214-226.

[23] Goldberg, T., Nevo, E. and Degani, G. (2011) Genetic Diverseness and Different Ecological Conditions in Salamnadra infraimaculata Larvae from Various Breeding Places. Animal Biology Journal, 2, 37-49.

[24] Goldberg, T., Eviatar, E. and Degani, G. (2009) Sequence Analysis of Mitochondrial DNA in Salamandra infraimmaculata Larvae from Populations in North Israel. South American Journal of Herpetology, 4, 268-274. http://dx.doi.org/10.2994/057.004.0310

[25] Degani, G., Goldberg, T. and Nevo, E. (2014) Genetic Variation in Salamandra infraimmaculata from Different Habitats Using Amplified Fragment Length Olymorphism. Journal of Biophysical Chemistry, 5, 54-66. http://dx.doi.org/10.4236/jbpc.2014.52007 